\title{
Crystal Structures of Dioxomolybdenum(VI) Complexes with ONS-Donor Ligands
}

\author{
Do-Won Kim, Uk Lec, ${ }^{\dagger}$ and Bon-Kweon Koo ${ }^{*}$ \\ Department of Chemistr, Cathotic University of Daegu, Gyeongsan 7/2-702, Korea \\ ${ }^{\dagger}$ Department of Chemistr. Pukyong National University, Busan 608-737, Korea \\ Received March 9. 2004
}

Key Words : Crystal structure. Dioxomolybdenum(VI) complexes, ONS-Donor

Molybdenum chemistry has received the intense attention because of its relevance to the active sites of molybdoenzymes. The presence of the eis-dioxomolybdenum(VI) cation, $\left|\mathrm{MoO}_{2}\right|^{2}$, in the oxidized forms of certain molybdoenzymes has stimulated both the search for new structures in which this moicty is coordinated to ligands containing nitrogen, oxygen and/or sulfur donors and also the study of their chemical, spectroscopic, electrochemical and structural propertics. ${ }^{1-7}$

Tridentate ONS-chelating ligands derived from thiosemicarbazide or dithiocarbazate of salicylaldehydes have been widely used for the preparation of transition metal complexes. ${ }^{8-10}$ The tautomerism (I) of these ligands as well as the well known tendency of sulfur donors to act as bridging ligands allow various structural possibilities for the corresponding metal complexes.

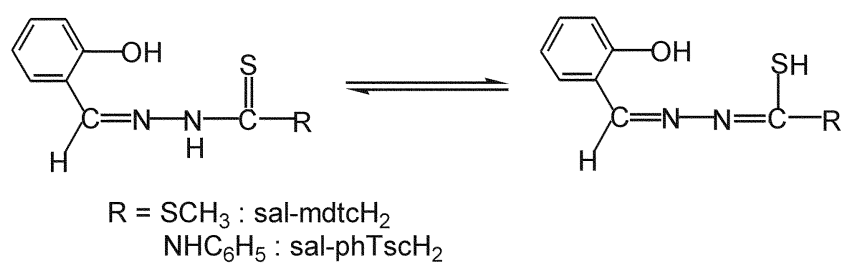

(I)

Related complexes with tridentate ONS ligand have been reported to undergo reversible oxo-transfer reactions involving molybdenum-(VI) and -(IV) species. ${ }^{11-16}$ As part of our studies on molybdenum(VI) complexes with nitrogen, oxygen, andior sulfur donor ligands, we have described the synthesis and spectroscopic and electrochemical properties for the molybdenum(VI) complexes with these ligand in previous paper, ${ }^{12}$ but no crystal structure has been reported. In this paper, we report the crystal structures on the complexes.

\section{Experimental Section}

Synthesis. The Schiff base ligands ${ }^{17}$ and both complexes, ${ }^{12}\left[\mathrm{MoO}_{2}\right.$ (sal-mdtc) $\left.(\mathrm{MeOH})\right](1)$ (sal-mdtc $=$ dibasic salicylaldehyde $\mathrm{S}$-methyldithiocarbazate ion) and $\left[\mathrm{MoO}_{2}\right.$ (sal-ph']sc) $(\mathrm{MeOH})] \cdot \mathrm{MeOH}$ (2) (sal-ph'l'sc = dibasic salicylaldehyde $\mathrm{N}$-phenylthiosemicarbazate ion) were prepared by

"Corresponding Author. e-mail: bkkoo(@)cuac.kr the procedure of literature reported previously, respectively. Analytical data are listed in reference. ${ }^{18}$

Crystal structure determination of 1 and 2. X-ray quality erystals of both complexes. 1 and 2 were obtained by slow cvaporation of a saturated dichloromethane solution of the brown powder. Data were collected on a STOE STAD $14^{16}$ four-circle (1) and Bruker SMART ${ }^{20}$ diffractometer (2) using graphite monochromatized Mo-K $\alpha$ radiation

Table 1. Crystal data and structure relinement for complexes 1 and 2

\begin{tabular}{|c|c|c|}
\hline & Complex 1 & Complex 2 \\
\hline Fimpirical formula & $\mathrm{C}_{10} \mathrm{II}_{12} \mathrm{MON}_{2} \mathrm{O}_{4} \mathrm{~S}_{2}$ & $\mathrm{C}_{10} \mathrm{ll}_{19} \mathrm{MoN}_{3} \mathrm{O}_{5} \mathrm{~S}$ \\
\hline Fit & 384.28 & 461.34 \\
\hline lemp (K) & $293(2)$ & $173(2)$ \\
\hline$\lambda(\dot{A})$ & 0.71069 & 0.71073 \\
\hline Crystal system & Monoclinic & Monoclinic \\
\hline Space group & P21/c & $\mathrm{P} 2 \mathrm{I} / \mathrm{n}$ \\
\hline$a(A)$ & $12.934(3)$ & $6.8259(3)$ \\
\hline$b(A)$ & $14.119(3)$ & $7.5881(3)$ \\
\hline$c(A)$ & $7.568(2)$ & $35.928(2)$ \\
\hline$\alpha\left({ }^{\circ}\right)$ & 90 & 90 \\
\hline$\beta\left(^{\circ}\right)$ & $95.13(3)$ & $95.102(1)$ \\
\hline$\gamma\left(1^{\circ}\right)$ & 90 & 90 \\
\hline$V\left(A^{i}\right)$ & $1376.5(6)$ & $1853.5(2)$ \\
\hline$\%$ & 4 & 4 \\
\hline $1 \mathrm{I}_{\mathrm{Lij \textrm {J }} \mathrm{c}}\left(\mathrm{Mg} / \mathrm{gl}^{3}\right)$ & 1.854 & 1.653 \\
\hline$\mu\left(\mathrm{mm}^{-1}\right)$ & 1.266 & 0.852 \\
\hline$F(000)$ & 768 & 936 \\
\hline Crystal si/e (mm) & $0.30 \times 0.15 \times 0.10$ & $0.5 \times 0.40 \times 0.20$ \\
\hline lhela range & $1.58-27.51^{\circ}$ & $1.14-28.25^{\circ}$ \\
\hline Index ranges & $\begin{array}{l}h 0 \rightarrow 16 . k-18 \\
\rightarrow 0.1-9 \rightarrow 9\end{array}$ & $\begin{array}{l}h \quad-9 \rightarrow 9 . k-8 \\
\rightarrow 9 . l-47 \rightarrow 33\end{array}$ \\
\hline Retlectionsiunique & $\begin{array}{l}3144 / 3] 44 \\
{[\text { Rint }=0.0000]}\end{array}$ & $\begin{array}{l}11456: 4294 \\
{[\text { Rint }=0.0444]}\end{array}$ \\
\hline Completeness to theta & $99.4 \%$ & $93.7 \%$ \\
\hline $\begin{array}{l}\text { Datarestraints } \\
\text { parameters }\end{array}$ & $3144 / 0 / 173$ & $4294 / 0 / 235$ \\
\hline$R[/>2 \sigma(\mathrm{I})]$ & $\begin{array}{l}R_{1}=0.0517 . \\
n \cdot R_{2}=0.0925\end{array}$ & $\begin{array}{l}R_{1}=0.0363 \\
1 R_{2}=0.0940\end{array}$ \\
\hline$R$ (all data) & $\begin{array}{l}R_{1}=0.0927 \\
W R_{2}=0.1131\end{array}$ & $\begin{array}{l}R_{1}=0.0405 \\
w R_{2}=0.1013\end{array}$ \\
\hline G.O.F. on $\mathrm{F}^{2}$ & 1.127 & 1.219 \\
\hline $\begin{array}{l}\text { Largest diff. peak } \\
\text { and hole }\end{array}$ & 0.624 and $-0.605 \mathrm{cA}^{-3}$ & 0.779 and $-1.041 \mathrm{cA}^{-3}$ \\
\hline
\end{tabular}


by $\theta-2 \theta(1)$ and $\pi-\omega(2)$ scans, respectively. In each case. unit cell parameters were determined by least-squares fit of 31 (1) and 7908 (2) reflections having $\theta$ values in the ranges of 9.5-10.3 (1) and 2.28-28.22 (2). Intensities of three check reflections were measured after every $\mathrm{l} h$ during the data collection to monitor the crystal stability for $\mathbf{l}$ and there was no significant change in the intensities of the check reflections. A numerical absorption correction for complex 1 was made : the transmission factor was 0.8128 (min.) and 0.8692 (max.), while complex 2 was not made. The structures were solved by direct method ${ }^{21}$ and refined on $F^{2}$ by full-matrix least-squares procedures. ${ }^{2-2}$ All non-hydrogen atoms were refined using anisotropic thermal parameters. Hydrogen atoms were included in the structure factor calculation at idealized positions by using riding model, but not refined. The data collection and structure solution parameters are listed in Table 1, together with standard discrepancy indicies, $R$ and $w R$.

\section{Results and Discussion}

The reaction of $\mathrm{MoO}_{2}$ (acac) $)_{2}$ with the Schiff base ligands derived from salicylaldehyde and $\mathrm{S}$-methyldithiocarbazate ${ }^{17}$ or 4-phenylthiosemicarbazide in methanol solution gave a monomeric molybdenum(VI) complex 1 and 2, respectively. Both complexes were identified by physicochemical methods and the resulting data were compared to the values of the

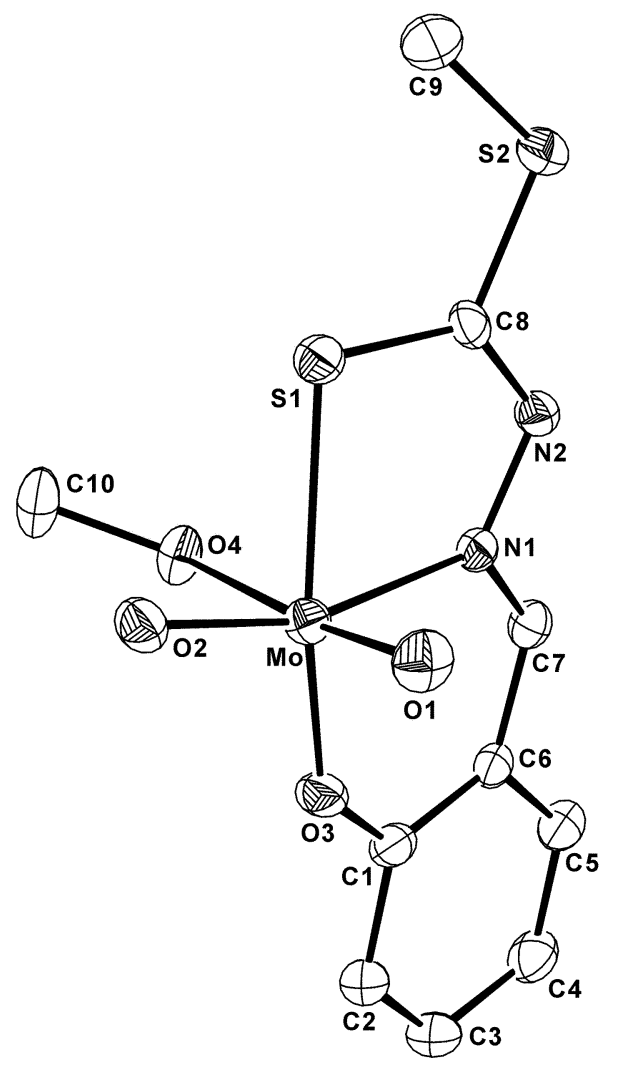

Figure 1. Ortepll1 $1^{2.3}$ drawing of I. Displacement ellipsoids are drawn at $30 \%$ probability level and $\mathrm{H}$ atoms have been omitted for clarity.

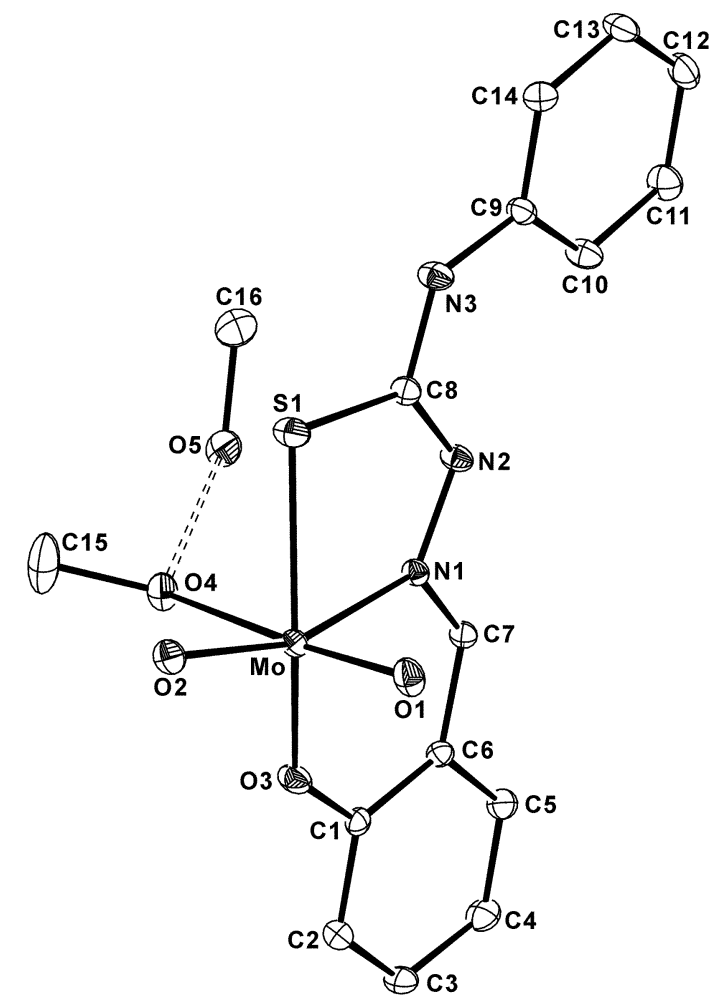

Figure 2. Ortepll ${ }^{2.3}$ drawing of 2 . Displacement ellipsoids are dratin at $30 \%$ probability level and $H$ atoms have hecn omitted for clarily.

literature. $^{12.16}$

The solid state molecular structures of the complex 1 and 2 are shown in Figure 1 and 2, respectively. Selected bond lengths and angles are listed in lable 2 and 3, respectively. The tridentate Schiff base ligand is bonded to the cis$\left[\mathrm{Mo}\left(\mathrm{VI}_{\mathrm{CO}} \mathrm{O}_{2}\right]^{2+}\right.$ core on a meridional plane through the phenolate- $\mathrm{O}$, the imine- $\mathrm{N}$, which is trans to an oxo group. and the deprotonated thiolate-S atoms forming one five- and

Table 2. Sclected bond lengths $(A)$ for complexes 1 and 2

\begin{tabular}{ccc}
\hline l3ond lenglhs & Complex 1 & Complex 2 \\
\hline Mo-O1 & $1.687(4)$ & $1.702(2)$ \\
Mo-O2 & $1.690(4)$ & $1.723(2)$ \\
Mo-O3 & $1.929(4)$ & $1.923(2)$ \\
Mo-N1 & $2.268(4)$ & $2.260(2)$ \\
Mo-S1 & $2.456(2)$ & $2.425(1)$ \\
Mo-O4 & $2.352(4)$ & $2.344(2)$ \\
C8-S1 & $1.721(6)$ & $1.759(3)$ \\
$\mathrm{C} 8-\mathrm{N} 2$ & $1.296(7)$ & $1.296(4)$ \\
$\mathrm{N} 2-\mathrm{N} 1$ & $1.407(6)$ & $1.404(3)$ \\
$\mathrm{N} 1-\mathrm{C} 7$ & $1.294(7)$ & $1.297(3)$ \\
$\mathrm{C} 7-\mathrm{C} 6$ & $1.434(8)$ & $1.445(4)$ \\
$\mathrm{C} 6-\mathrm{C} 1$ & $1.406(8)$ & $1.405(4)$ \\
$\mathrm{CI}-\mathrm{O3}$ & $1.339(7)$ & $1.344(3)$ \\
$04-\mathrm{H} 17$ & & 0.820 \\
$\mathrm{H} 17 \cdots 05$ & & 1.830 \\
$04 \cdots 05$ & & $2.642(3)$ \\
\hline
\end{tabular}


Table 3. Selected bond angles (") for complexes 1 and 2

\begin{tabular}{|c|c|c|}
\hline Angles & Complex 1 & Complex 2 \\
\hline $\mathrm{Ol}-\mathrm{Mo}-\mathrm{O} 2$ & $105.3(2)$ & $105.1(1)$ \\
\hline $\mathrm{Ol}-\mathrm{Mo}-\mathrm{O} 3$ & $99.8(2)$ & $99.9(1)$ \\
\hline $\mathrm{Ol}-\mathrm{Mo}-\mathrm{O} 4$ & $171.8(2)$ & $171.2(1)$ \\
\hline Ol-Mo-Nl & $95.6(2)$ & $92.4(1)$ \\
\hline $\mathrm{Sl}-\mathrm{Mo}-\mathrm{Ol}$ & $94.9(2)$ & $98.1(1)$ \\
\hline $\mathrm{S} 1-\mathrm{Mo}-\mathrm{O} 2$ & $90.4(2)$ & $89.6(1)$ \\
\hline $\mathrm{Sl}-\mathrm{Mo}-\mathrm{O} 3$ & $134.8(1)$ & $153.0(1)$ \\
\hline $\mathrm{Sl}-\mathrm{Mo}-\mathrm{O} 4$ & $82.5(1)$ & $81.3(1)$ \\
\hline $\mathrm{Sl-Mo-Nl}$ & $76.2(1)$ & $75.9(1)$ \\
\hline $\mathrm{O} 2-\mathrm{Mo}-\mathrm{O} 3$ & $105.4(2)$ & $104.8(1)$ \\
\hline $\mathrm{O} 2-\mathrm{Mo}-\mathrm{O} 4$ & $82.6(2)$ & $83.7(1)$ \\
\hline $\mathrm{O} 2-\mathrm{Mo}-\mathrm{Nl}$ & $156.1(2)$ & $158.8(1)$ \\
\hline $\mathrm{O} 3-\mathrm{Mo}-\mathrm{O} 4$ & $80.1(2)$ & $77.8(1)$ \\
\hline $\mathrm{O} 4-\mathrm{Mo}-\mathrm{N} \mathrm{l}$ & $76.3(2)$ & $78.9(1)$ \\
\hline C7-Nl-Mo & $126.5(4)$ & $124.3(2)$ \\
\hline $\mathrm{C} 7-\mathrm{Nl}-\mathrm{N} 2$ & $112.7(4)$ & $112.4(2)$ \\
\hline $\mathrm{O} 4-\mathrm{H} 17 \cdots 05$ & & 169.8 \\
\hline
\end{tabular}

one six-mentbered chelate ring. The sixth coordination site around Mo is occupied by a solvent methanol molecule. thereby providing a distorted octahedral coordination environment around $\mathrm{Mo}$ in which the coordinated $\mathrm{MeOH}$ lie trans to another oxo group. In general the structure resembles that of the cis-dioxomolybdenum(VI) complex with tridentate Schiff base ligand of thiocarbodihydrazone of salicylaldeide. ${ }^{\text {li }}$

In both the complexes 1 and 2, the cis-bond angles around Mo range from $75.9(1)^{\circ}$ to $76.2(1)^{\circ}$ for Nl-Mo-SI to 105. $\mathrm{L}(\mathrm{l})^{\circ}-105.3(2)^{\circ}$ for $\mathrm{O} 1-\mathrm{Mo}-\mathrm{O} 2$, while the range of transbond angles extends from $153.0(1)^{\circ}$ to $154.8(1)^{\circ}$ for O3-Mo$\mathrm{SI}$ and $171.2(1)^{\circ}-171.8(2)^{\circ}$ for $\mathrm{O}-\mathrm{Mo}-\mathrm{O} 4^{1 i}$ To a large extent these distortions stem from the incorporation of Mo into a five-membered ring. The Mo-O bond length [1.689(4) $\AA$ for 1 and $1.713(2) \AA$ for 2] and the $\mathrm{O}-\mathrm{Mo}-\mathrm{O}$ bond angle [105.3(2) for 1 and 105.1(1) for 2] are comparable to other such data reported for the $\mathrm{MoO}_{2}$ group. ${ }^{13.24 .25}$ The Mo-S1 and Mo-N1 bond lengths and other metric parameters for Mo-S1-C8-N2-N1 ring are similar to those reported for other five-membered rings of this general type. ${ }^{8}$ The N1-C7 [1.294(7) A-1.297(3) A] and N2-C8 [1.296(4) A-1.296(7) $\mathrm{A}]$ distances indicate that these correspond to double bonds (normal single bond is $1.364 \mathrm{~A}$ ). ${ }^{8}$ The Mo-O4 [2.352(4) $\mathrm{A}$ in 1 and $2.344(2) A$ in 2 ] bond length is relatively long due to the trans effect ${ }^{26}$ of the terminal oxide ligands and the coordinated solvent molecule $\left(\mathrm{CH}_{3} \mathrm{OH}\right)$ is labile. The metric parameters for the six-membered rings $\mathrm{Mo}-\mathrm{O} 3-\mathrm{Cl}-\mathrm{C} 6-\mathrm{C} 7-$ $\mathrm{Nl}$ for 1 and 2 are unexceptional and compare closely to those in related molecules. ${ }^{8}$ Both of the five- and sixmembered rings which are formed upon coordination of ligand are almost plane: for the complex of 1 . the mean deviations of the planes Mo-S1-C8-N2-N1 and Mo-N1-C7$\mathrm{C} 6-\mathrm{Cl}-\mathrm{O} 3$ from the least-square plane are 0.0829 and $0.0035 \mathrm{~A}$. respectively and each of the dihedral angles of the Mo-S1-C8-N2, Mo-O3-C1-C6, and Mo-N1-C7-C6 to the plane, Mo-Sl-C8-N2-N1 is $3.77(0.09), 11.27(0.16)$, and $11.37(0.19)^{\circ}$. Also. both planes in complex 2 are nearly plane with the magnitude of the Mo-SI-C8-N2. Mo-O3-CIC6. and Mo-NI-C7-C6 dihedral angles to the plane, Mo-SIC8-N2-NI (mean deviation is $0.0764 \AA$ ) of $3.3(0.1), 14.4$ $(0.1)$. and $7.0(0.1)^{\circ}$, respectively.

In case of 2, the unit cell contains one methanol solvent molecule per molecule. which is hydrogen-bonded to the molybdenum-bound methanol molecule. The O4*O5 separation and the $\mathrm{O} 4-\mathrm{H} \cdots \mathrm{O}$ 5 angle are $2.642(3) \AA$ and 169.8, respectively. ${ }^{27}$

\section{Conclusions}

Two dioxomolybdenum(VI) complexes with the ONSdonnor ligands. salicylaldeliyde S-methylditliocarbazate and salicylaldelyde S-phenylthiosemicarbazate have been synthesized and characterized. In both complexes, the structure consists of molybdenyl moiety. one tridentate Schiff base ligand. and a solvent methanol molecule that occupies the sixth metal coordination site. The geometry around Mo is distorted octahedral. The tridentate ligand is bonded to the cis- $\mathrm{MOO}_{2}$ core on a meridional plane through phenolated-O deprotonated-S. and an imine nitrogen atom forming one five- and one six-membered chelate ring. The molecules of these two display essentially sumilar coordination geometry.

Supporting information available. Cry stallographic data for the structure reported here have been deposited with the Cambridge Crystallographic Data Center (Deposition No. CCDC-232954 (1) and 232953 (2)). The data can be obtained free of charge via www.ccdc.cam.ac.uk/conts/ retrieving.html (or from the CCDC, 12 Union Road, Cambridge CB2 IEZ, UK: fax: +441223 336033: e-mail depositaccdc.cam.ac.uk).

\section{References}

1. Zhai, Y. L.: Xu, X. X.; Wang, X. Polvhedron 1992, 11.415.

2. Stiefel. E. I. Prog. Inorg. Chem. 1977. 22. 1.

3. Stiefel. E. I.: Miller. K. F.: Bruce. A. E.: Pariyadath. N.: Heinecke. J.: Corbin. I. L: : Berg. T. M.: Hodgson. K. O. In Mohbdenmm Chentistry of Biological Significance: Newton, W. E.; Otsuka, S. Eds. Plenum: New York, 1980, p 279 and refs. therein.

4. Spence. J. T. Coord. Chem. Rev 1983, 48.59.

5. Stelzig. L.: Kotte. S.: Krebs. B. J. Chem. Soc. Dalton. Trans. 1998. 2921.

6. Koo. B. K.: Mo. S. Т. Buh. Korean Chem. Soc. 1999. 20. 1105

7. Jang. Y. J: Mo. S. J: Koo. B. K. Bull. Koream Chem. Soc. 1998. 19. 587 .

8. Bustos. C.: Burchihardt. O.: Scluebler. R.: Carrillo, D.: Arif. A. M.: Cowley. A. H.: Nunn. C. M. Inong Chem. 1990. 29. 3996.

9. Rana. A.: Dinda. R.: Ghosh. S.: Blake. A. Polvhedron 2003. 22. 3075 .

10. Rana. A: Dinda. R: Sengupta, P: Ghosh. S: Falvello. L. R. Polwedron 2002, 21, 1023 .

11. Koo, B. K. Lee, U. Bull. Korean Chem. Soc, 2002. 23, 613.

12. Koo. B. K.: Kim. H. T. Bull. Korean Chem. Soc. 1994. 15. 766.

13. Dutta. S. K.: McConville. D. B.: Youngs. W. J: Chaudhury. M. 
Ihorg. Chem. 1997.36,2517.

14. Bhattacharjee. S.: Bhattacharyya. R. J. Chem. Soc. Daltom Trams. 1992. 1357

15. Bhattacharjee. S.: Bhattacharyya. R. J. Chent. Soc. Dalon Trans. 1993,1151

16. Purohit. S: Koler A. P. Prasad, L. S.: Manoharan. P. T: Ghosh, S. Horg them $1989,28,3735$

17. Jang. Y. J.: Mo. S. J.: Koo. B. K. Buh. Konew them. Soc, 1998 19. 1124 .

18. Analytical data for (1). Yield: $0.227 \mathrm{~g}\left(59^{\circ} 0\right)$. mp $248-250^{\circ} \mathrm{C}$. Anal. Caled. for $\mathrm{C}_{10} \mathrm{H}_{12} \mathrm{~N}_{2} \mathrm{O}_{4} \mathrm{~S}_{2} \mathrm{Mo}$ ): $\mathrm{C}, 31.26:$ H. 3.15: N. 7.29: S. 16.69. Found: C. 31.34: H. 3.01; N. 7.50; S, 16.72. Significant

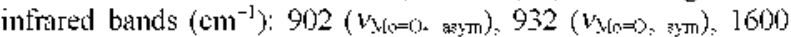
$\left(v_{\mathrm{C}=\mathrm{N}}\right)$. 'H NMR (200 MHz. DMSO-d $): 2.60$ (s.3H. S-CHs). 3.18 (d. $3 \mathrm{H} . \mathrm{CH}_{3} \mathrm{OH}$ ) 4.14 (q. IH. $\left.\mathrm{CH}_{3} \mathrm{OH}\right), 6.95-7.77$ (m. $4 \mathrm{H} . \mathrm{ArH}$ ). 8.93 (s. IH. $\mathrm{N}=\mathrm{CH}$ ). (2). Yield: $0.277 \mathrm{~g}\left(60^{\circ} \circ\right)$. mp 205-208 ${ }^{\circ} \mathrm{C}$. Anal. Caled for $\mathbf{C}_{16} \mathrm{H}_{19} \mathbf{N}_{3} \mathrm{O}_{5} \mathrm{SMo}$ : C. 41.66: H. 4.15: N 9.11: S. 6.95. Found: $\mathrm{C} .41 .23: \mathrm{H}_{3} 4.35$, N. 9.25; S. 7.02. Significant infrared

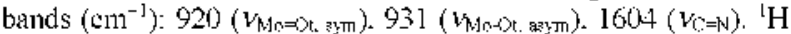

NMR (200 MHz. DMSO-d $s): \delta 3.16\left(d .6 \mathrm{H}_{3}, \mathrm{CH}_{3} \mathrm{OH}\right), 4.12$ (q. 2H. $\mathrm{CH}_{3} \mathrm{OH}$ ). $6.89-7.77$ (m. $9 \mathrm{H}$. AlH). 8.82 (s. $\mathrm{IH} . \mathrm{N}=\mathrm{CH}$ ). 9.70 (s. IH. NH)

19. STOE STADH A-RED \& X-SH.APE. X-ray structure evaluation package: STOE-Cie Gmbh: Hilpertstrase 10, D64295, Darmstadt. Germany, 1996.

20. Bruker. SI LART, Bruker AXS Inc.: Madison. Wisconsin, USA, 1998.

21. Sheldrick. G. M. Acta Chst 1990. A $\$ 6.467$

22. Sheldrick. G. M. SHELAS97-2 and SHELLZ97-2: University of Gottingen: Gottingen, Germany, 1997.

23. Farrugia, L. J. J. Appl. Cryst 1997, 30.565.

24. Berg, J. M. Holm. R. H. J. Am. Chem. Soc. 1984, 106, 3035.

25. Liimatainen. J.: Lehtonen. A.: Sillanpaa. R. Polvhedron 2000. 19. 1133.

26. Crain. T. A.: Harlan. E. W.: Synder. B. S.: Whitener. M. A.: Holm. R. H. Inokr Chent 1989.28,2082

27. Perlepes, S. P.: Libby, E.: Streib. W. E.; Folting, K.: Christou. G. Polvhedon 1992, 11.923. 